\title{
Prorok Jonasz zapowiedzią Chrystusa w świetle Komentarza do Księgi Jonasza św. Hieronima
}

Powszechnie znane i często cytowane jest stwierdzenie św. Hieronima, że „nieznajomość Pisma Świętego jest nieznajomością Chrystusa”' ${ }^{1}$ To głębokie przekonanie motywowało tego wielkiego człowieka i uczonego do ciągłego zgłębiania tajemnicy Bożego Słowa, utrwalonego w świętych księgach ${ }^{2}$. Jego wkład w poznanie Biblii budzi do dzisiaj niezwykły podziw i uznanie ${ }^{3}$. Podjął przecież nie tylko prace nad przekładami Pisma Świętego ${ }^{4}$, ale także starał się objaśnić i skomen-

1 Zdanie to znajdujemy w Prologu Komentarza do Księgi proroka Izajasza (PL 24,17). Zostało ono także zacytowane przez Konstytucję dogmatyczną o Objawieniu Bożym Soboru Watykańskiego II w punkcie 25.

2 Hieronim był przekonany, że nawet porządek słów w Biblii może stanowić i wyrażać tajemnicę Bożą: „Ja bowiem nie tylko wyznaję, lecz wprost i otwarcie oświadczam, że w tłumaczeniu pism greckich - wyjąwszy Pismo św., gdzie i porządek słów jest tajemnicą - wyrażam nie słowo za słowem, lecz myśl za myślą" (Ep. 57,5), przekład ks. J. Czuja, Św. Hieronim, Listy, t. I, Warszawa 1952, s. 401.

3 Benedykt XVI poświęcił Hieronimowi dwie katechezy (7 i 14 listopada 2007), ukazując go jako człowieka, w którego życiu Biblia zajmowała centralne miejsce: przetłumaczył ją na język łaciński, komentował w swoich dziełach, a zwłaszcza starał się konkretnie żyć według jej wskazań przez długie lata swojej ziemskiej egzystencji, pomimo trudnego i porywczego charakteru, jakim, jak wiadomo, obdarzyła go natura”, Katecheza z dnia 7 listopada 2007 r. pod tytułem Św. Hieronim (I), tekst polski za „L'Osservatore Romano”, wydanie polskie, $1 / 299$ (2008), s. 50.

4 Najpierw na zlecenie papieża Damazego poprawił, opierając się na tekście greckim, łacińskie tłumaczenia Nowego Testamentu używane w Rzymie. W 384 r. zajął się także psałterzem, wprowadzając poprawki według LXX. Następnie w Betlejem rozpoczął pracę nad poprawkami Starego Testamentu według LXX, zamieszczonej w Heksapli Orygenesa. Ok. 391 r. podjął decyzję przekładu na nowo Starego Testamentu z języka oryginalnego (hebrajskiego, względnie aramejskiego). Dzieło to zakończył w roku 406. Por. P. Antin, Essai sur Saint Jérôme, Paris 1951, s. 147-155; B. Altaner, A. Stuiber, Patrologia, Warszawa 1990, s. 522-524 wraz z podstawową bibliografią. 
tować natchnione teksty, zarówno Starego ${ }^{5}$, jak i Nowego Testamentu ${ }^{6}$. Na uwagę zasługują także prace translatorskie ${ }^{7}$, liczne homilie ${ }^{8}$, pisma dogmatyczno-polemiczne ${ }^{9}$, historyczne ${ }^{10}$ oraz około sto dwadzieścia autentycznych listów ${ }^{11}$, które powstały w okresie całego życia Hieronima ${ }^{12}$.

Wśród wielu biblijnych opracowań znajduje się także niewielki Komentarz do Księgi proroka Jonasza - In Ionam o charakterze alegoryczno-typologicznym, który będzie przedmiotem naszej refleksji w niniejszym artykule ${ }^{13}$.

Najpierw zostaną krótko zarysowane okoliczności powstania Komentarza, a następnie najważniejsze założenia warsztatu egzegetycznego Hieronima, wyrażone i zastosowane w wyżej wymienionym dziele. W kolejnym punkcie zwró-

5 Komentarz do Księgi Psalmów, Komentarz do Księgi Eklezjastesa, komentarze do wszystkich proroków (Jeremiasz - tylko rozdziały 1-32), alegoryczna rozprawa $O$ wizji Izajasza oraz historyczna Wykładnia dziesięciu wizji Iz 13-23, Kwestie żydowskie w Księdze Rodzaju, por. P. Antin, dz. cyt., s. 154-163 oraz B. Altaner, A. Stuiber, dz. cyt., s. 525-526.

6 Komentarz do Listu do Filipian, Komentarz do Listu do Galatów, Komentarz do Listu do Efezjan, Komentarz do Listu do Tytusa, Komentarz do Ewangelii według św. Mateusza, a także Komentarz do Apokalipsy autorstwa Wiktoryna z Petawium. Por. tamże, s. 525.

7 Przekłady homilii Orygenesa, fragmenty dzieła $O$ zasadach, dzieł Euzebiusza z Cezarei (Kroniki, Onomastikon), Księga nazw hebrajskich, pismo O Duchu Świętym Dydyma oraz Reguła dla mnichów Pachomiusza, Teodora i Horsiesiego wraz z ich Listami. Por. tamże, s. $262-524$.

8 Homilie na temat psalmów, homilie na temat Ewangelii według św. Marka i inne kazania na temat poszczególnych tekstów biblijnych. Por. tamże, s. 525.

9 Dyskusja lucyferianina $z$ katolikiem, Przeciw Helwidiuszowi o wiecznym dziewictwie błogosławionej Maryi, Przeciw Jowinianowi, Przeciw Wigilancjuszowi, Przeciw Janowi Jerozolimskiemu, Apologia przeciw ksiegom Rufina, Dialog przeciw pelagianom. Por. tamże, s. 526-527.

10 Kontynuacja Kronik Euzebiusza i katalogu O sławnych mężach, biografie: Żywot Pawła $z$ Teb, Malchusa i Hilariona. Por. tamże, s. 45, 309, 527.

11 Por. tamże, 527-528; na temat twórczości Hieronima por. także M. Simonetti, Między dosłownością a alegorią, Kraków 2000, s. 329-347.

12 Por. A. Eckmann, Hieronim ze Strydonu. Nauka $w$ służbie rozumienia i interpretacji Pisma Świętego, AK 422 (1979), s. 422-429.

13 Wydanie tekstu: Migne, PL 25, 1117 B-1152; Saint Jérôme, Sur Jonas, tekst i tłum. P. Antin, SCH 43, Paris 1956; Jérôme, Commentaire sur Jonas, tekst i tłum. Y.-M. Duval, SCh 323, Paris 1985; wydanie polskie: Święty Hieronim, Komentarz do Księgi Jonasza, tłum. i oprac. L. Gładyszewski, Źródła myśli teologicznej 8, Kraków 1998. Z tego przekładu zaczerpniemy wszystkie fragmenty Komentarza, cytowane w niniejszym artykule. Podajemy odniesienie do części Komentarza (JonKom) oraz strony według wydania polskiego. Przekład został poprzedzony ciekawym wstępem biblijnym autorstwa bpa Stanisława Gądeckiego (s. 5-32) oraz wstępem patrystycznym (s. 33-54), do którego będziemy się odwoływać. Opracowanie zawiera także bogatą bibliografię, dotyczącą św. Hieronima oraz Księgi proroka Jonasza (s. 55-80). 
cimy uwagę na interpretację osoby i historii proroka Jonasza jako typologicznej zapowiedzi osoby i dzieła Jezusa z Nazaretu.

\section{Komentarz do Księgi Jonasza}

Okoliczności powstania In Ionam są dość łatwe do ustalenia. W prologu do Komentarza autor sam deklaruje, że rozpoczyna objaśnianie proroka Jonasza po trzech latach przerwy w pracach egzegetycznych oraz wymienia inne dzieła, które powstały w tym okresie:

Prawie trzy lata upłynęły od czasu, gdy objaśniałem pięciu proroków, a mianowicie Micheasza, Nahuma, Habakuka, Sofoniasza i Aggeusza. Oddany innym zajęciom nie mogłem dokończyć tego, co rozpocząłem. Napisałem bowiem [w tym czasie] księgę o sławnych mężach oraz dwa tomy przeciwko Jowinianowi; z kolei apologię oraz do Pammachiusza o najlepszym sposobie tłumaczenia, a także do Nepocjana czy o Nepocjanie dwie księgi, oraz inne rzeczy, które trzeba by długo wymieniać. Po upływie zatem tak znacznego czasu, jakby powracając do pierwszej miłości, od Jonasza właśnie rozpoczynam komentowanie ${ }^{14}$.

Te informacje służą do szczegółowego określenia czasu powstania Komentarza: wcześniej niż koniec roku 396, bo wymienione na początku dzieło De viris illustribus lub De scriptoribus ecclesiasticis powstało w Betlejem w 392-393 roku, a musi mieścić się w okresie trzech lat wspomnianych przez Hieronima, później zaś niż lato 396, gdyż ostatnie wspomniane dzieło (żałobna pochwała Nepocjana po jego śmierci, znana jako List 60 do Heliodora) powstało w lipcu 396 roku. A zatem wydaje się bardzo prawdopodobne, że Komentarz do Księgi proroka Jonasza powstał między lipcem a grudniem 396 roku $^{15}$ i został zadedykowany Chromacjuszowi, który był biskupem Akwilei ${ }^{16}$.

We wstępie do Komentarza Hieronim wymienia także powody, dla których podjął się objaśnienia tekstu Księgi Jonasza. Pierwszy to „powrót do ojczyzny”17, tzn. do ulubionego, można by wręcz powiedzieć, upragnionego, ukochanego zajęcia objaśniania tekstów prorockich. Drugim powodem jest zamiar dania jasnego i poprawnego komentarza tej księgi biblijnej, zwłaszcza że istnieją roz-

14 JonKom, Wstęp, s. 83-84.

15 Por. M. Simonetti, dz. cyt.; podobnie Girolamo, Commento al Libro di Giona, traduzione, introduzione e note a cura di Nicoletta Pavia, Roma 1992, s. 10; szczególnie przypis 10.

16 Więcej szczegółów na temat dedykacji oraz niektórych manuskryptów, które w miejsce imienia Chromacjusza mają imię Pammachiusza, zob. tamże, s. 11-13.

17 Przekład polski oddaje to jako „powrót do pierwszej miłości”, por. przypis 9 na s. 84 . 
maite interpretacje ${ }^{18}$, które - zdaniem Hieronima - nie spełniają należycie swojej funkcji objaśnienia tekstu prorockiego. Sam pisze:

Wiem, że dawni pisarze kościelni tak greccy, jak łacińscy, wiele na temat tej księgi powiedzieli, ale podnoszonymi kwestiami nie tyle wyjaśnili jej treść, ile raczej ją zaciemnili. Wskutek tego właśnie ich interpretacja wymaga objaśnienia; czytelnik odchodzi od tej lektury o wiele bardziej niepewny, niż był, zanim do niej przystąpił. Nie mówię tego, by pomniejszać wielkie umysły i własną chwałą innym uwłaczać; komentator jednak jest zobowiązany niejasne miejsca krótko i jasno wytłumaczyć; nie wolno mu zmierzać bardziej do popisywania się własną wymową niż dążyć do wyjaśnienia treści komentowanego dzieła ${ }^{19}$.

Aby wypełnić postawione sobie zadanie, Hieronim przyzywa pomocy samego Jonasza, a przez niego Ducha Świętego, do którego odnosi imię proroka: „Modlę się, by ten, który jest typem Zbawiciela i który przez to, że przebywał "trzy dni i trzy noce we wnętrzu wieloryba" (Mt 12,40) stanowi wieszczą zapowiedź zmartwychwstania Pana, nam także udzielił dawnego zapału, abyśmy zasłużyli na przyjście do nas Ducha Świętego. Jeżeli «Jonasz» znaczy tyle, co "gołębica", a gołębica z kolei odnosi się do Ducha Świętego (por. Mt 3,16), to my również postaramy się objaśnić gołębicę pod wpływem łaski zstąpienia na nas Gołębicy"20.

\section{Założenia metodyczne św. Hieronima wyrażone w Komentarzu}

Komentarz powstaje po trzech latach przerwy w pracy egzegetycznej, ale Hieronim pozostaje wierny głównym założeniom dawnej metody objaśniania tekstu biblijnego. Co prawda, swoich poglądów metodologicznych nie sformułował nigdzie w sposób systematyczny, to jednak wyraźnie widać dwa zasadnicze elementy jego warsztatu egzegetycznego: z jednej strony - przywiązywanie uwagi do rozumienia dosłownego (historia), a z drugiej poszukiwanie także sensu duchowego (intelligentia spiritualis). W ten sposób łączy metody wyjaśniania tekstu biblijnego wypracowane przez dwie najważniejsze szkoły egzegetyczne: antiocheńską (dosłowność) i aleksandryjską (alegoria) ${ }^{21}$.

18 Monograficzne opracowanie na ten temat: Y.-M. Duval, Le livre de Jonas dans la littérature chrétienne grecque et latine. Sources et influence du Commentaire sur Jonas de saint Jérôme, t. I-II, Paris 1973.

19 JonKom, Wstęp, s. 84-85.

20 Tamże, s. 84.

21 Doskonałe opracowanie tego zagadnienia w M. Simonetti, dz. cyt., s. 157-236. Na temat egzegezy Ojców Kościoła, zob. St. Wielgus, Badania nad Bibliq w starożytności $i$ w średniowieczu, Lublin 1990, s. 30-73; M. Starowieyski, Egzegeza Ojców Kościoła, AK 488 (1990), s. $25-36$. 
Jednym z ważnych elementów, wskazujących na fakt doceniania przez Hieronima dosłownego znaczenia tekstu, było dążenie do jak najbardziej wiernego przekładu Księgi Jonasza. Układ objaśnianego tekstu jest następujący. Każdy werset jest najpierw przełożony na łacinę z języka hebrajskiego, a następnie Autor podaje przekład łaciński tekstu greckiego Księgi, zaczerpniętego z LXX, czasami $\mathrm{w}$ pełnym brzmieniu cały werset ${ }^{22}$, innym razem tylko różniące się sformułowania między tekstem oryginalnym (hebrajskim) a tłumaczeniem Septuaginty ${ }^{23}$. $\mathrm{W}$ ten sposób Hieronim pragnie najpierw dobrze zrozumieć oryginalny tekst biblijny i jasno zaznaczyć ewentualne różnice między nim a przekładem greckim Septuaginty. Jeśli oba teksty nie różniły się między sobą, Hieronim pomijał drugą wersję $e^{24}$. Kiedy w przekonaniu Hieronima różnica była znacząca, nawiązywał do niej w komentowaniu danego fragmentu ${ }^{25}$. Hieronim należy niewątpliwie do interpretatorów Biblii, którzy odwoływali się do tekstu oryginalnego. Większość egzegetów nie znała języka hebrajskiego i dlatego nie miała też możliwości uwzględniania w komentarzach oryginalnego tekstu biblijnego. Ponadto panowało powszechne przekonanie, że tłumacze LXX pracowali - podobnie jak autorzy tekstu hebrajskiego - pod natchnieniem Bożym i dlatego odwoływanie się do tekstu hebrajskiego wydawało się zbyteczne. Hieronim jest więc jednym z pierwszych egzegetów, który brał pod uwagę oryginalny tekst biblijny Starego Testamentu, by w sposób właściwy go zrozumieć i wyjaśnić ${ }^{26}$. Było to też możliwe dzięki ogólnemu wykształceniu Hieronima, które miało wyraźnie charakter filologiczny. Uważa się go za „pierwszego filologa wśród Ojców”27. Warto też wspomnieć w tym miejscu, że dla lepszego poznania opisywanych miejsc zwiedzał kraje biblijne, zwłaszcza Palestynę i Egipt. W ten sposób wykorzystał całe swoje przygotowanie i umiejętności do lepszego zrozumienia i wyjaśnienia Słowa Bożego.

22 JonKom, I, 3b, s. 92.

23 JonKom, I, 1, s. 88.

24 JonKom, I, 3a, s. 89.

25 JonKom, I, 3b, s. 93.

26 W Ep. 106,2 czytamy: „Otóż, jeśli idzie o Nowy Testament, to w wypadku gdy Łacinnicy mają wątpliwości, a między poszczególnymi egzemplarzami zachodzi różnica, uciekamy się do oryginalnego języka greckiego, w którym spisany został ten Nowy Dokument. Jeśli natomiast w zakresie Starego Testamentu zachodzi różnica między Grekami a Łacinnikami, wtedy zwracamy się do oryginału hebrajskiego, aby odszukać w strumykach to, co płynie ze źródła”, przekład ks. J. Czuja, Św. Hieronim, Listy, t. II, Warszawa 1953, s. 365.

27 A. Bober, Antologia patrystyczna, Kraków 1965, s. 211. 
Hieronim rozpoczyna zazwyczaj swoje poszukiwania egzegetyczne od wyjaśniania sensu dosłownego, który określa terminami: historia, fundamenta historiae, litterae. Już w prologu do Komentarza nawiązuje do tradycji żydowskiej, aby lepiej sprecyzować pochodzenie Jonasza. Opierając się na geografii Palestyny, podaje dokładne miejsce urodzenia proroka, korzysta z tekstów deuterokanonicznych, sięga do pisarzy pogańskich, aby lepiej przedstawić kontekst historyczny, odnoszący się do życia i dzieła proroka ${ }^{28}$. Po przytoczeniu tych wszystkich danych Hieronim konkluduje, że to stanowi podstawy historyczne (hoc quantum ad historiae pertinet fundamenta ${ }^{29}$. W poszukiwaniu sensu dosłownego, literalnego, odwołuje się często do analizy filologicznej poszczególnych terminów: nazwy wielkiej ryby ${ }^{30}$, określenia właściwej liczby dni pokuty i postu w Niniwie ${ }^{31}$, nazwy rośliny, w cieniu której znalazł schronienie prorok ${ }^{32}$, podaje szereg szczegółów geograficznych i topograficznych, a także ciekawostki turystyczne ${ }^{33}$. Nawet przebywanie Jonasza w brzuchu wielkiej ryby uznaje za historycznie prawdzi$w^{34}$. Jest przekonany, że trzeba zaczynać wyjaśnianie tekstu od poszukiwania właśnie sensu historycznego, a dopiero potem wnikać w sens duchowy: „zbadajmy najpierw historię i przed sensem mistycznym przyjrzyjmy się najpierw znaczeniu literalnemu"35. Niekiedy Hieronim zadowala się tylko krótką uwagą na temat znaczenia dosłownego ${ }^{36}$ albo stwierdza, że sens literalny nie jest trudny do odnalezienia ${ }^{37}$ lub nie budzi żadnych wątpliwości ${ }^{38}$.

$\mathrm{Z}$ drugiej jednak strony Hieronim poszukuje często także sensu duchowego, który określa takimi terminami, jak: tropologia, allegoria, intellectus mysticus oraz anagoge. W czasach Hieronima pojęcia te nie miały jeszcze ściśle ustalonego znaczenia i dlatego były stosowane często zamiennie na oznaczenie, najogólniej mówiąc, sensu duchowego ${ }^{39}$. Pierwsze określenie tropologia odnajdujemy

28 JonKom, Wstęp, s. 85-86.

29 Tamże, s. 86: „To tyle co do podstaw historycznych”.

30 JonKom, II, 1, s. 107.

31 JonKom, III, 4b, s. 124.

32 JonKom, IV, 6, s. 134-136. Tutaj warto także zwrócić uwagę, że dla wyjaśnienia nazwy rośliny, pod którą schronił się Jonasz, Hieronim odwołuje się także do innych języków niż sam hebrajski: „Zamiast «dynia» czy «bluszcz» w tekście hebrajskim czytamy ciceion, którego odpowiednik w języku syryjskim czy punickim brzmi ciceia".

33 JonKom, I, 3b, s. 93.

34 JonKom, II, 2, s. 109.

35 JonKom, IV, 6, s. 136.

36 JonKom, II, 11, s. 120.

37 JonKom, II, 4a, s. 111.

38 JonKom, II, 6b, s. 115.

39 Przykładem takiego fragmentu, w którym zostały nagromadzone terminy odnoszące się do warsztatu egzegetycznego Hieronima, jest JonKom, I, 3b, s. 93-95. Por. Jérôme, Commentaire sur Jonas, s. 249-250, przyp. 22. 
w Komentarzu cztery razy ${ }^{40}$. Według Hieronima, oznacza ona jeden z trzech sposobów interpretacji sensu dosłownego, polegającego na poszukiwaniu głębszego znaczenia i tłumaczenia go w sensie moralnym, przynoszącym pożytek dla duszy $^{41}$. Jeden raz termin ten zostaje użyty jako synonim typologii ${ }^{42}$. Podobnym sposobem interpretowania tekstu była allegoria, przez którą rozumiał sens przenośny i alegoryczny. Hieronim zachowuje jednak pewną ostrożność w zastosowaniu topologii i alegorii oraz przestrzega przed interpretowaniem w równym stopniu wszystkiego za pomocą tych metod. Wymownym przykładem jest wypowiedź komentatora:

Roztropnego czytelnika należy poprosić, by nie oczekiwał zachowania tego samego porząaku dla topologii i dla historii. Apostoł wprawdzie odnosi Agar i Sarę do dwóch Testamentów (por. Ga 4,22-31), a jednak nie wszystko, o czym opowiada historia, możemy objaśnić topologicznie. [...] Czy całą historię tego miejsca podciągniemy pod zasadę alegorii? Czy raczej każde miejsce według odrębnej historii otrzyma odrębne duchowe znaczenie? Jak więc te świadectwa mają własne wyjaśnienia i jak ani wydarzenia poprzedzające, ani następujące nie wymagają tej samej alegorii, tak również prorok Jonasz bez pewnego niebezpieczeństwa dla interpretatora w całości nie będzie mógł być odniesiony do Pana. I to nie dlatego, że w Ewangelii napisano: „Plemię przewrotne i wiarołomne żąda znaku, ale żaden znak nie będzie mu dany, prócz znaku Jonasza. Albowiem jak Jonasz był trzy dni i trzy noce we wnętrznościach wielkiej ryby, tak Syn Człowieczy będzie trzy dni i trzy noce w łonie ziemi” (Mt 12,39-40; BT). Pozostałych także wydarzeń, jakie rozegrały się w związku z tym prorokiem, nie można w jednakowym porządku odnosić do Chrystusa. Oczywiście, gdzie tylko to bez zagrożenia będzie możliwe, my również będziemy starali się tak postąpićc ${ }^{43}$.

Warto także zaznaczyć, że Hieronim używa jeszcze dwóch innych pojęć na oznaczenie sensu duchowego: "sens mistyczny” (intellectus mysticus) ${ }^{44}$ oraz „anagogia” (anagoge) ${ }^{45}$.

40 JonKom, I, 3b - dwa razy, raz w formie tropologice, s. 94; I, 6, s. 98; IV, 10, s. 139.

41 Ep. 120,12: Trojaki jest w sercu naszym sposób i zasada pojmowania Pisma św.: pierwsza - abyśmy je rozumieli według historii; druga - według przenośni, trzecia - według pojmowania duchowego. W historii zachowuje się kolejność tego, co napisane; w przenośni od znaczenia dosłownego wznosimy się do głębszego i cokolwiek u poprzedniego narodu dokonało się cieleśnie, tłumaczymy w sensie moralnym i obracamy na pożytek naszej duszy, przekład ks. J. Czuja, Św. Hieronim, Listy, t. III, Warszawa 1954, s. 150.

42 JonKom, IV, 10, s. 139.

43 JonKom, I, 3b, s. 94-95.

44 JonKom, IV, 6, s. 136.

45 JonKom, II, 4, s. 111 wraz z przypisem 17. 
Poszukiwanie sensu przenośnego, duchowego interpretowanych tekstów prowadziło także do egzegezy typologicznej, która stała się jednym z rozpowszechnionych sposobów interpretacji tekstu biblijnego, stosowanym $z$ dużym powodzeniem przez pisarzy chrześcijańskich pierwszych wieków ${ }^{46}$. Wypływała ona przede wszystkim z głębokiego przekonania o jedności obu Testamentów ${ }^{47}$. Polegała zasadniczo na ukazywaniu zgodności między Starym i Nowym Testamentem. Jako główną ideę przewodnią przyjęła przekonanie, że wydarzenia i osoby Starego Testamentu są wieszczymi zapowiedziami (typami) wydarzeń i osób Nowego Testamentu. Hieronim używa technicznego pojęcia typus pięć razy ${ }^{48}$, natomiast termin typologia nie występuje w Komentarzu, choć warto zaznaczyć jeszcze raz, że w czasach Hieronima nie określono jeszcze jednoznacznego sensu poszczególnych terminów, a nawet różnica między alegorią a typologią nie była zbyt jasna ${ }^{49}$.

Hieronim dokonuje interpretacji typologicznej historii proroka Jonasza, aby ukazać, że dzieło Chrystusa zostało zapowiedziane już w Starym Testamencie przez figurę, jaką stanowi Jonasz. Wszystkie wysiłki egzegetyczne Hieronima zmierzają właściwie w jednym kierunku. Pragnie mianowicie ukazać, że postać Jonasza oraz jego misja w Niniwie są zapowiedzią osoby Jezusa Chrystusa i jego misji zbawienia całej ludzkości. Już na samym początku Autor stwierdza, że zanosi modlitwy do Jonasza jako do tego, „który jest typem Zbawiciela i który przez to, że przebywał "trzy dni i trzy noce we wnętrzu wieloryba" (Mt 12,40) stanowi wieszczą zapowiedź zmartwychwstania Pana"50. Dla Hieronima najwyższym autorytetem przy wyjaśnianiu owej typologii jest sam Jezus, bowiem „nikt lepiej nie wyjaśni własnego typu, niż Ten właśnie, kto sam natchnął proroków i w swoich sługach uprzedzająco zarysował przyszłą prawdę"51. Skoro „tajemnicze znaczenie tych słów wyjaśnił Pan w Ewangelii (por. Mt 12,40), zbędne więc powtarzać to samo albo też opowiadać coś innego, niż przedstawił właśnie Ten, który cierpiał" "52. Mamy tutaj także wyrażone głębokie przekonanie Hieronima,

46 Na temat egzegezy typologicznej, zob. J.N.D. Kelly, Początki doktryny chrześcijańskiej, Warszawa 1988, s. 62-65 oraz M. Simonetti, dz. cyt., passim; M. Grilli, Quale rapporto tra i due Testamenti? Riflessione critica sui modelli ermeneutici classici concernenti l'unità delle Scritture, Bologna 2007, s. 39-45.

47 Por. J.N.D. Kelly, dz. cyt., s. 58-61; M. Gołębiewski, Jedność Pisma Świętego jako zasada hermeneutyczna, CT 53 (1983) 1, s. 5-17.

48 JonKom, Wstęp, 2 razy s. 84, 87; I, 5, s. 97; II, 2, s. 108; IV, 6, s. 137.

49 Por. M. Grilli, dz. cyt., s. 40. Na temat współczesnej dyskusji o różnicy między alegorią a typologią, zob. B.S. Childs, Teologia biblica. Antico e Nuovo Testamento, Casale Monteferrato 1998, s. 27-29.

50 JonKom, Wstęp, s. 84.

51 Tamże, s. 87.

52 JonKom, II, 1b, s. 108. 
że prawdziwym interpretatorem Pisma jest sam Chrystus, a postać i los Jonasza w typiczny sposób zapowiadają osobę i dzieło Mesjasza.

\section{Najważniejsze elementy typologii chrystologicznej}

Zgodnie z założeniem wyrażonym w prologu do Komentarza, Hieronim dokonuje egzegezy typologicznej dziejów Jonasza, szukając paraleli między prorokiem a Jezusem. Interpretacja typologiczna jest „czasem nawet [...] tak prowadzona, jakby obydwie te postacie miały się w obrazie komentarza utożsamiać czy na siebie dokładnie nakładać"53. Przyjrzyjmy się zatem kilku konkretnym przykładom odnoszenia losów Jonasza do osoby Chrystusa oraz interpretacji teologicznej, która płynie z owych odniesień i zależności.

\subsection{Imię Jonasza zapowiedzią bóstwa i misji Jezusa}

W potrójny sposób Hieronim wyjaśnia znaczenie imienia Jonasz i stara się je zinterpretować w odniesieniu do Zbawiciela ${ }^{54}$. Jedno ze znaczeń dotyczy Jezusa, który cierpiał. Opierając się na tropologii, Hieronim wyjaśnia znaczenie imienia Jonasz, wyciągając wniosek, że imię proroka oznacza "gołębia” albo „bolejącego"55. Pierwsze znaczenie imienia jest o tyle oczywiste - według Hieronima - że Duch Święty w postaci gołębia zstąpił na Chrystusa i spoczął na Nim (por. Mk 1,10; Łk 3,22; J 1,32-33). Dlatego gołąb może wprost odnosić się do Jezusa, który został napełniony Duchem Świętym. Wydaje się, że jest to rozwinięcie i bliższe wyjaśnienie myśli, która pojawiła się już na samym początku Komentarza. We wstępie Hieronim stwierdza mianowicie, że „Jonasz znaczy tyle, co gołębica, a gołębica z kolei odnosi się do Ducha Świętego (por. Mt 3,16)"56.

Drugie znaczenie imienia prorockiego to - według egzegety - „bolejący”. Na poparcie swego stwierdzenia Hieronim odwołuje się do dwóch fragmentów Pisma św., w których szukał uzasadnienia takiego wyjaśnienia imienia Jonasza. Chrystus był „bolejący”, bo sam odczuwał ból naszych ran, przyjmując ludzkie cierpienia, płakał nad Jerozolimą (por. Łk 19,41) i przez Jego cierpienie wszyscy

53 L. Gładyszewski, Wstęp patrystyczny, w: Święty Hieronim, Komentarz, s. 50.

54 Od tego miejsca wykorzystuję częściowo materiał, który znajduje się w moim artykule: Typologia Chrystusa cierpiacego w „Komentarzu do Ksiegi Jonasza”, w: P. Podeszwa, W. Szczerbiński, Ad sapientaim cordis. Księga pamiątkowa dedykowana księdzu profesorowi Ludwikowi Gładyszewskiemu w 70. rocznice urodzin, Gniezno 2002, s. 153-157, 160-162, 169-176.

55 JonKom, I, 1, s. 88.

56 JonKom, Wstęp, s. 84. 
zostali uleczeni (Iz 53,5) ${ }^{57}$. Taki dobór tekstów biblijnych nie jest przypadkowy. Zapowiadają one potrójny temat, który Hieronim będzie rozwijał w dalszej części Komentarza. Odczuwanie przez Chrystusa ludzkich ran i cierpień wskazuje na fakt, że Jezus, będąc Bogiem, przyjął na siebie wszystko to, co ludzkie. Stając się człowiekiem i dobrowolnie podejmując cierpienie, utożsamił się w nim z całym rodzajem ludzkim. Płacz nad Jerozolimą oznacza wzajemne odniesienie między Jezusem a narodem żydowskim. Wielokrotnie pojawi się przeciwstawienie między zbawieniem pogan a potępieniem Izraela, który odrzuca wiarę w Jezusa-Mesjasza ${ }^{58}$. I wreszcie ostatni fragment biblijny, który mówi o uleczeniu ludzkości, wskazuje to, czym będzie męka i śmierć Chrystusa, jakie przyniesie owoce całemu stworzeniu.

Dla całości obrazu należy dodać, że Hieronim wyprowadził z imienia Jonasza jeszcze trzecie odniesienie do Chrystusa. Tym razem nie posłużył się etymologią samego wyrazu Jonasz, ale zwrócił uwagę na to, że Biblia wspomina, iż Jonasz był synem Amittaja (2 Krl 14,25), a „Amati” oznacza prawdę ${ }^{59}$. Dlatego sądził, że imię to lepiej odnosi się do Chrystusa, który jest Synem Bożym. A skoro Bóg jest Prawda $(\mathrm{J} 14,6)$, to Jego Syn jest Synem Prawdy ${ }^{60}$. Taki sposób rozumowania i zestawienia tekstów nie jest bez znaczenia. Nazwanie Jezusa Synem Prawdy podkreśla bowiem Jego boskie pochodzenie i oznacza uznanie w Jezusie Syna Boga Prawdziwego.

Jak widać, samo wyjaśnienie etymologiczne imienia proroka i odniesienie go do Jezusa wskazuje na treści teologiczne. Ukazuje Chrystusa jako Tego, który został napełniony Duchem Świętym i działał w mocy tego Ducha. Hieronim podkreślił też wyraźnie bóstwo Jezusa, nazywając Go Synem Prawdy. A rozumiejąc imię Jonasza jako „bolejący”, egzegeta zapowiedział dramat Chrystusa. Będzie go odsłaniał przez cały czas komentowania wydarzeń z życia proroka Jonasza. Będzie to dramat męki, śmierci Chrystusa dla zbawienia i ocalenia nie tylko narodu wybranego, ale całego rodzaju ludzkiego.

\subsection{Ucieczka proroka do Tarszisz typem Wcielenia Syna Bożego}

Hieronim podjął temat Wcielenia Jezusa, które rozumiał jako początek Jego misji na ziemi. Miała ona polegać na dobrowolnym przyjęciu cierpienia. Dlatego egzegeta ukazał Wcielenie Jezusa jako pewnego rodzaju przygotowanie do spełnienia

57 JonKom, I, 1, s. 88.

58 JonKom, IV, 1, s. 131, gdzie komentując losy Jonasza, stwierdza, że „również dla znaczenia historycznego bardziej właściwe jest imię «bolejącego", które wskazuje na utrudzonego proroka, przygniecionego nieszczęściami podróżowania i morskiej katastrofy”.

59 JonKom, Wstęp, s. 85.

60 JonKom, I, 1, s. 88. 
owej misji. Traktował przyjęcie przez Syna Bożego ludzkiego ciała jako powolne wchodzenie Chrystusa w kenozę i uniżenie.

Bóg skierował do Jonasza słowo, w którym polecił prorokowi, aby udał się do Niniwy i głosił tam Boże wezwanie do nawrócenia. Jonasz wzbraniał się przed podjęciem swojej misji i dlatego zamiast do Niniwy udał się do Tarszisz. W ten sposób chciał uniknąć konieczności wypełnienia zadania, zleconego przez Boga. Prorok podążył do miasta Tarszisz, które geograficznie może oznaczać konkretne miejsce, ale Hieronim był bardziej skłonny przyjąć, że przez tę nazwę należy raczej rozumieć morze. Owo rozumienie jest zbliżone do tego, jakie na ogół wyraża tradycja żydowska ${ }^{61}$, która wydawała się Hieronimowi bardziej logiczna, gdyż uważał, że prorok nie miał zamiaru uciekać do jakiegoś ściśle określonego miejsca, ale wchodząc na statek, starał się umknąć dokądkolwiek ${ }^{62}$. Według komentatora, takie zachowanie odpowiadało też bardziej przestraszonemu prorokowi, który chciał schwycić pierwszą, nadarzającą się okazję do odpłynięcia.

Ten właśnie epizod z życia proroka Jonasza, to znaczy początek jego misji, jest według Hieronima typem Wcielenia Jezusa. Zbawiciel także otrzymał od Boga misję udania się do Niniwy, która oznacza cały świat ${ }^{63}$. Niegodziwość Niniwy, to znaczy świata, doszła przed oblicze Boga, który posyła swego Syna. Chcąc wypełnić tę misję, Jezus opuścił swój dom i ojczyznę, to znaczy niebo, a przybrawszy ludzkie ciało, w pewnym stopniu uciekł do Tarszisz, które oznacza morze ludzkiej doczesności ${ }^{64}$. Tak więc ucieczka Jonasza stała się typem opuszczenia przez Jezusa niebios i przyjęcia ludzkiego ciała, a tym samym wejścia w historię tego świata. Wcielenie Syna Bożego było pewnego rodzaju ucieczką od Ojca i dlatego w rozumieniu św. Hieronima musiało oznaczać dla Chrystusa także początek Jego cierpienia.

Jonasz wołał z głębin morskich do Boga, skarżąc się, że rzucił go w serce morza i że ogarnęły go fale. Hieronim sądzi, że nietrudno jest zrozumieć skargę proroka, skierowaną do Boga, ponieważ zamknięty w brzuchu wieloryba znalazł się w odmętach morskiej głębiny, zewsząd otoczony wodami. Jego położenie wywołało strach i dlatego pełen obaw, ale i ufności, wzywał Bożej pomocy. Hieronim odniósł to również do Zbawiciela; wyjaśnił, że Wcielenie Chrystusa było zstąpieniem do tego świata pełnego odmętów i burz. W porównaniu z niebiosami,

61 JonKom, I, 3a, s. 90-91: „Hebrajczycy na ogół utrzymują, że Tarszisz oznacza morze, zgodnie ze słowami: "W tchnieniu gwałtownym poniszczysz statki Tarszisz» (Ps 47,8), to jest morza. U Izajasza zaś: "Płaczcie, statki Tarszisz»".

62 Tamże.

63 JonKom, I, 2, s. 88: „Został posłany do pięknej Niniwy, to jest do świata, bo oczyma ciała nie widzimy niczego piękniejszego niż świat".

64 JonKom, I, 3a: „O naszym Panu i Zbawicielu możemy również powiedzieć, że opuścił swój dom i ojczyznę, a przyjmując ciało w jakiś sposób uciekł z niebios i przybył do Tarszisz, to znaczy na morze doczesności”. 
miejscem niebieskiej szczęśliwości i przebywania Chrystusa razem z Ojcem, wszelkie ziemskie mieszkanie okazuje się pełne fal i burz. Ta świadomość napełnia Chrystusa lękiem i staje się przyczyną Jego cierpienia. Według analogii, czyli sensu duchowego, przebywanie proroka $\mathrm{w}$ „sercu morza” Hieronim interpretuje jako znalezienie się Zbawiciela wśród wszelkich doświadczeń, z wyjątkiem grzechu ${ }^{65}$.

W dalszej części modlitwy zanoszonej przez Jonasza do Boga z głębin morskich prorok żalił się, że został „odrzucony od spojrzenia oczu Boga" ${ }^{66}$. W tym miejscu Hieronim przeszedł bezpośrednio do tłumaczenia sensu typologicznego i dał odpowiedź, w jakim znaczeniu te słowa mogą odnosić się do Zbawiciela. Zdaniem egzegety, Chrystus wypowiedział te słowa właśnie po Wcieleniu, kiedy mianowicie przyjął postać sługi i doświadczył różnego rodzaju słabości. Gdy był w niebiosach razem z Ojcem, nie miał powodów, aby mówić, że został odrzucony od wejrzenia Boga. Wtedy był razem z Bogiem - Światłem, cieszył się Jego Światłem i w Ojcu jako źródle Światła sam był Światłością. Skoro jednak znalazł się na morzu tego świata, które było wstrząsane różnego rodzaju burzami, i przyjął ludzkie ciało, zaczął doświadczać ludzkich uczuć i wszystkich przeciwności, które niósł ze sobą świat. Wtedy też poczuł się odrzucony od wejrzenia oczu Ojca. Hieronim podkreśla wyraźnie, że Jezus wypowiedział powyższe słowa „jako człowiek"67.

Egzegeta obrazowo przedstawia, że Wcielenie Chrystusa łączy się z opuszczeniem przez Syna Bożego miejsca przebywania razem z Ojcem w wiecznej szczęśliwości, z przyjęciem ludzkiego ciała oraz zamieszkaniem wśród ludzi. Wcielenie było więc nie tylko początkiem misji Jezusa, ale także początkiem Jego zbawczego cierpienia. Fakt przyjęcia ludzkiego ciała spowodował, że Jezus przyjął wraz z ciałem wszystkie ludzkie słabości, stał się podobny do ludzi we wszystkim, oprócz grzechu (por. Hbr 4,15). Zbawiciel doświadczył nie tylko ludzkich słabości, ale także przeciwności świata. To w ludzkim ciele Mesjasz podjął swoją misję głoszenia nawrócenia i pokuty całemu światu, który tutaj symbolizuje Niniwa, oraz misję uspokojenia morza doczesności, pełnego fal, nawałnic i burz, a w ten sposób dzieło ocalenia i zbawienia całego rodzaju ludzkiego.

65 JonKom, II, 4a, s. 111.

66 JonKom, II, 5a, s. 112-113.

67 Tamże: „Skoro jednak "przybyłem na głębinę morza» i przyodziałem się w ludzkie ciało, ludzkie naśladuję uczucia i mówię: Zostałem odrzucony od spojrzenia Twych oczu. To powiedziałem jako człowiek". 


\subsection{Jonasz w morskich głębinach figurą męki krzyżowej Chrystusa}

Od Wcielenia całe życie Jezusa na ziemi było już w pewnym stopniu cierpieniem Zbawiciela ${ }^{68}$. Tak rozumiał to św. Hieronim. Ale autor wskazał też wyraźnie na moment, kiedy Chrystus podjął cierpienie fizyczne, dobrowolnie przyjmując śmierć na krzyżu jako ofiarę za całą ludzkość. Ten moment został także - zdaniem egzegety - zapowiedziany w sposób typologiczny przez proroka Jonasza.

Prorok wsiadł na okręt i udał się w podróż do Tarszisz. Kiedy statek był na pełnym morzu, rozszalała się straszliwa burza. Dla Hieronima morze - jak powiedzieliśmy - było symbolem świata doczesnego. Wzburzone i rozszalałe morze to według niego świat, który leżał w mocy zła. Jonasz na statku natomiast to Chrystus przebywający wśród ludzi. Prorok płynął do Tarszisz, które może oznaczać także drogę do kontemplowania radości ${ }^{69}$. Osoba proroka była więc nie tylko typem Chrystusa, przebywającego wśród ludzi, ale także figurą Jezusa, który pragnął doprowadzić ludzi do wiecznej radości przebywania tam, gdzie On przebywał razem z Ojcem. Przeciwko Jonaszowi burzyły się żywioły świata, znajdującego się pod panowaniem zła. Prorok wiedział, że tylko jego śmierć może uratować statek. Wyrzucenie Jonasza w morskie odmęty miało stać się ocaleniem dla żeglarzy, którym wydawało się to nieprawdopodobne, aby śmierć jednego człowieka mogła ocalić statek od niebezpieczeństwa. Dlatego prorok sam pozwolił na to, aby żeglarze wyrzucili go w morze. Był przekonany, że w ten sposób uciszą się wiatry, a burza uspokoi się z chwilą jego śmierci. Scena, która rozegrała się na statku, a przede wszystkim sam moment znalezienia się Jonasza w morskich głębinach, stanowiła dla Hieronima zapowiedź męki i cierpień Chrystusa na drzewie krzyża ${ }^{70}$. Jak morze srożyło się przeciwko Jonaszowi, tak świat, pełen zła i przemocy, burzył się przeciwko Temu, który przyniósł ludziom zbawienie. I dopiero śmierć krzyżowa Chrystusa uspokoiła żywioły doczesności: „Jeżeli zauważymy, że przed męką Chrystusa na świecie błędy szalały w podmuchach różnych sprzecznych poglądów, że zagrożony był statek i cały ludzki rodzaj, to jest stworzenie Pana, że natomiast po Jego męce nastała cisza wiary i zapanował pokój na ziemskim okręgu, że wszystko stało się bezpieczne i dokonało się nawrócenie do Boga, zobaczymy, jak po wrzuceniu Jonasza ustało wzburzenie morza"71.

68 Pomijam tutaj interpretację Hieronima odnoszącą się do cierpienia Jezusa ze względu na Jego świadomość, że podjęcie misji zbawczej całej ludzkości może spowodować odrzucenie własnego narodu, por. P. Podeszwa, dz. cyt., s. 157-162.

69 JonKom, I, 12, s. 102.

70 JonKom, I, 3b, s. 94.

71 JonKom, I, 15, s. 105. 
Hieronim w swej typologii poszedł jeszcze dalej. Żeglarze nie chcieli śmierci niewinnego człowieka. Wzbraniali się przez zabiciem proroka. Myśleli, że zdołają własnymi siłami uratować statek z niebezpieczeństwa. Woleli raczej sami zginąć, niż dopuścić się zbrodni ${ }^{72}$. Poznali już, że lepiej stracić życie, niż popaść $\mathrm{w}$ grzech $^{73}$. W ten sposób żeglarze zostali uznani przez Hieronima za zapowiedź postawy narodów pogańskich, a scena, kiedy marynarze zastanawiają się nad ewentualną przyczyną burzy morskiej i rolą Jonasza, za typ procesu, który rozegrał się przed obliczem rzymskiego namiestnika Piłata. Ich wzbranianie się przed wyrzuceniem Jonasza do morza oraz modlitwa zanoszona do Boga, aby nie czynił ich odpowiedzialnymi za niewinną śmierć tego człowieka, zostały zinterpretowane przez Hieronima jako figura Piłatowych słów, który skazując Jezusa na śmierć, powiedział, że jest czysty od krwi tego człowieka ${ }^{74}$.

Takie zestawienie obrazów pokazało też, że Chrystus podjął mękę zupełnie dobrowolnie. Jego cierpienia były odpowiedzią Boga na zło świata, które nie chciało dopuścić do tego, aby Jezus doprowadził ludzi do Ojca, do pełni radości. Według Hieronima, w typologii tej kryje się myśl, że śmierć Chrystusa spowodowała uciszenie burzy, a więc przyniosła spokój światu, a ludziom ocalenie, i odtąd bezpieczne będzie żeglowanie po falach doczesności ${ }^{75}$. W postępowaniu żeglarzy Hieronim dostrzegał postawę pogan, którzy przyjęli owoce cierpień Chrystusa i uwierzyli w Zbawiciela. W ten sposób autor zapowiedział już temat uniwersalnego zbawczego sensu cierpienia i śmierci Chrystusa.

\section{Teologiczne znaczenie interpretacji typologicznej proroka Jonasza}

Zastosowanie typologicznej egzegezy tekstu biblijnego dawało możliwości prezentacji poglądów teologicznych egzegety, który się tą metodą posługiwał. Analizowane obrazy pozwalały wydobyć nie tylko treści egzegetyczne czy elementy wspólne dla typu i jego antytypu, ale także, a może przede wszystkim, stały się okazją do wyrażenia określonych przekonań teologicznych. Komentarz Hieronima ze swej natury nie stanowił wyjątku. I tutaj, ilekroć autor przystępował do omawiania poszczególnych starotestamentowych typów, tylekroć starał się wzbogacić swoją analizę wnioskami teologicznymi.

72 JonKom, I, 13, s. 103.

73 JonKom, I, 14, s. 104.

74 Tamże.

75 JonKom, I, 13, s. 103-104: „[żeglarze] myśleli, nie znając jeszcze tajemnicy Tego, który miał cierpieć, że statek można wyrwać z niebezpieczeństwa, gdy tymczasem właśnie utopienie Jonasza oznaczało ratunek dla statku”. 
Niewątpliwie jednym z najważniejszych pytań, na które pragnął dać odpowiedź egzegeta, był problem bóstwa i człowieczeństwa Jezusa oraz skutków Jego zbawczego misterium. Warto uświadomić sobie fakt, że dzieło Hieronima powstało w czasie, gdy nauka chrystologiczna nie była w pełni zdefiniowana. Upłynęło jeszcze sporo czasu, zanim sobór w Chalcedonie orzekł dogmat o bóstwie i człowieczeństwie Syna Bożego oraz ściśle określił terminologię teologiczną. Do tego czasu ciągle trwały poszukiwania i dociekania, przez które pisarze kościelni pragnęli możliwie najlepiej wyrazić tę podstawową dla chrześcijanina prawdę.

Pierwszym zagadnieniem podjętym przez Hieronima była kwestia pochodzenia i istnienia Jezusa Chrystusa. Według komentatora, moment przyjścia Jezusa na świat nie był równoznaczny z zaistnieniem Jezusa jako Syna Bożego. Jako druga osoba Trójcy Świętej Chrystus istniał odwiecznie razem z Ojcem i Duchem Świętym. Wzajemna zależność między Ojcem i Synem polegała na tym, że jak obrazowo ukazał to Hieronim - Syn był świątynią Ojca, a Ojciec świątynią Syna $^{76}$. Ponadto Syn, żyjąc w doskonałej jedności z Ojcem, cieszył się światłem, które było w Bogu, i sam w Nim był światłem ${ }^{77}$. Chrystus - Logos był u Ojca jako Bóg - Słowo ${ }^{78}$. Chrystus więc jako Syn Boży był równy Ojcu ${ }^{79}$. Bóstwo Jezusa i Jego odwieczne istnienie podkreślił też egzegeta poprzez bezpośrednie odniesienie do Jezusa słów św. Jana, że „przez Niego wszystko się stało, a bez Niego nic się nie stało" $(\mathrm{J} 1,13)^{80}$. To był dla Hieronima jeden $\mathrm{z}$ argumentów na prawdę, że Jezus wraz z Ojcem istniał odwiecznie i miał swój udział w dziele stwórczym samego Boga. A skoro Jezus istniał odwiecznie jako doskonała jedność z Bogiem Ojcem, to Jego Bóstwo jest oczywiste. Ważne wydaje się położenie akcentu przez Hieronima na jedność i równość bóstwa Ojca i Syna. Były to niewątpliwie echa polemik z herezjami, które nie chciały uznać w Jezusie bóstwa równego Ojcu i przedstawiały Go jako kogoś niższego lub jako byt pośredni między odwiecznym Stwórcą a stworzeniem. Hieronim zdecydowanie odrzucił taki sposób rozumienia Jezusa i ukazał Syna Bożego w doskonałej równości z Ojcem.

Odwiecznie istniejący Syn spełnił wolę swego Ojca i zaistniał w historii tego świata i ludzkości. Zaistnienie w czasie to Wcielenie, które jest nie tylko wydarzeniem brzemiennym w skutki dla Chrystusa, ale także dla świata i całego stworzenia. Według Hieronima, był to moment jakby opuszczenia przez Syna

76 JonKom, II, 5b, s. 113.

77 Tamże.

78 Tamże.

79 JonKom, II, 5a, s. 113.

80 JonKom, IV, 10-11, s. 139-140. Hieronim wspomina o poglądach Marcjona i Ariusza. 
Bożego miejsca niebieskiej szczęśliwości, domu Ojca, i przyjęcia ludzkiego cia-

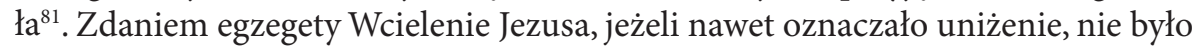
jednak „skażeniem Chrystusa”, gdyż wzięte z niepokalanej Dziewicy ciało było Jego świątynią, ponieważ pozostawał Bogiem ${ }^{82}$. Przyjęcie ludzkiego ciała niosło ze sobą ściśle określone konsekwencje dla Chrystusa. W nim Jezus doznawał wszystkich ludzkich uczućc ${ }^{83}$ i był we wszystkim doświadczony oprócz grzechu ${ }^{84}$. Chrystus był w pełni człowiekiem, nie tylko dlatego, że posiadał ludzkie ciało, ale miał też duszę, którą wraz z ciałem - pisał Hieronim - raczył przyjąć dla naszego zbawienia ${ }^{85}$. Hieronim uznał w Jezusie nie tylko prawdziwego Boga, ale także prawdziwego człowieka. I choć nie mówił w Komentarzu wprost o zjednoczeniu natury ludzkiej i boskiej Chrystusa, używając takiej właśnie terminologii, to jednak prawda ta jest obecna w jego rozumieniu i przedstawieniu Wcielonego Syna Bożego. Jezus istniejący w ludzkim ciele objawił też - jak uczy Hieronim - swego Ojca, z którym stanowił jedno, i Ducha Świętego, którym był napełniony i w mocy którego działał. To przekonanie Hieronima ujawnia się szczególnie przy wyjaśnianiu etymologii imienia Jonasz, o którym pisaliśmy wcześniej. Przypomnijmy tutaj tylko najważniejsze elementy. Samo imię proroka, które według typologii zapowiada Chrystusa, objawia ludziom fakt, że Jezus to Syn Prawdy odwiecznej ${ }^{86}$, to Gołąb, napełniony Duchem Świętym, który spoczął na Nim ${ }^{87}$, a także Cierpiący sługa, posłuszny woli Ojca Niebieskiego ${ }^{88}$. Ponadto komentator odnosi do Chrystusa dwa obrazy biblijne, nazywając Go „światłem świata” (J 8,12; 9,5) ${ }^{89}$ oraz „słońcem sprawiedliwości” (Ml 4,2) ${ }^{90}$. Możemy tu z pewnością odnaleźć już wcześniej wskazaną myśl, że Jezus, przebywając ze swoim Ojcem, był Światłością w Światłości, a Wcielenie było momentem przyjścia Światłości na ziemię.

Tak rozumiany Syn Boży podjął cierpienie i mękę, które stały się początkiem realizacji zbawczego planu Ojca wobec całej ludzkości. Hieronim rozumiał cierpienie Chrystusa bardzo szeroko. Właśnie rozpoczęło się ono - zdaniem egzegety - już na samym początku misji Syna Bożego, a więc w momencie przyjęcia ludzkiego ciała i wejścia przez Wcielenie w historię człowieka. Odtąd całe życie Chrystusa stało się powolnym wchodzeniem w cierpienie i przygotowywaniem do ostatecznego aktu odkupienia świata. Podjęcie więc męki i śmierci krzyżowej

81 JonKom, I, 3a, s. 91.

82 JonKom, II, 7b, s. 117.

83 JonKom, II, 5a, s. 113.

84 JonKom, II, 4b, s. 112.

85 JonKom, II, 6b, s. 115.

86 JonKom, I, 1-2, s. 88.

87 JonKom, Wstęp, s. 84.

88 JonKom, I, 1-2, s. 88.

89 JonKom, IV, 10-11, s. 140-141.

90 JonKom, IV, 7-8, s. 137. 
było już pewnego rodzaju następstwem tego, co zostało zapoczątkowane przez Wcielenie, było ostatecznym spełnieniem woli Ojca i największym posłuszeństwem Syna w stosunku do Ojca. Dobrowolnie podjęte cierpienie przez Jezusa i ofiarowane Ojcu za całą ludzkość przyniosło zbawienie i odkupienie całemu stworzeniu. Hieronim nie powiedział jednak wiele o typologii samej męki Jezusowej. Według niego, Jezus, który podjął dobrowolne cierpienie, niejako poddał się żywiołom tego świata i dozwolił, aby one odniosły zwycięstwo. Ich zwycięstwo wnet okazało się jednak tylko pozorne i to, co według zewnętrznego osądu zostało pokonane, ostatecznie zwyciężyło ${ }^{91}$.

Hieronimowe rozumienie cierpienia i samego Chrystusa cierpiącego jest bardzo szerokie. Na cierpienie składa się bowiem Wcielenie Syna Bożego, podjęcie przez Niego męki i śmierci na krzyżu, a także zstąpienie Jezusa do otchłani92. Tak pojmowane dzieło Jezusa przyniosło określone owoce rodzajowi ludzkiemu. Wcielenie umożliwiało nie tylko rozpoczęcie dzieła zbawczego i objawiało Ojca w Synu, ale było przede wszystkim - zdaniem Hieronima - zstąpieniem Syna Bożego do człowieka, aby dzięki Jego uniżeniu mógł dojść do nieba rodzaj ludzkii ${ }^{93}$ W ten sposób Jezus pragnął wynieść ludzi do uczestnictwa w życiu samego Boga, aby odtąd człowiek przebywał tam, gdzie Syn był z Ojcem ${ }^{94}$. Tak więc cierpienie Chrystusa zapoczątkowane w momencie Wcielenia Syna Bożego przyniosło ludziom dar wyniesienia ich do życia w samym Bogu. Ale przyjęcie przez Boga ludzkiego ciała i przezwyciężanie w nim wszystkich słabości ukazało też ludzkości drogę zwycięstwa dobra nad wszystkimi mocami zła.

Podjęcie przez Chrystusa męki i śmierci krzyżowej było rozumiane przez Hieronima jako złożenie siebie samego w ofierze Ojcu Niebieskiemu. Syn złożył ofiarę Ojcu, aby ratować ludzkość. Tę prawdę wyraża Hieronim w określeniu, że z jednej strony Chrystus sam jest składającym ofiarę i jednocześnie samą złożoną ofiarą. Był prawdziwym Arcykapłanem i Barankiem, który ofiarował samego siebie za nas ${ }^{95}$. Hieronim uważał, że przyjmując cierpienia cielesne Chrystus prosi Ojca jako Arcykapłan, „aby w jego ciele został uwolniony cały lud” ${ }^{\prime 6}$. W ten sposób modlitwa Jonasza staje się typem modlitwy arcykapłańskiej Jezusa, zanoszonej za cały rodzaj ludzki. Ofiara Chrystusa została przyjęta przez Ojca i dokonało się zbawienie świata. Polegało ono na tym, że świat stał się spokojny, to znaczy uciszyły się moce zła, panujące na nim przed męką Jezusa. Nastąpiło

91 JonKom, I, 12, s. 102.

92 Na temat typologii zstąpienia Chrystusa do otchłani i znaczenia teologicznego tego faktu, zob. P. Podeszwa, dz. cyt., s. 157-162, 162-164, 172-174.

93 JonKom, I, 1-2, s. 89.

94 JonKom, II, 5a, s. 113.

95 JonKom, II, 10, s. 120.

96 JonKom, II, 8b, s. 119. 
uspokojenie płynące z wiary i dokonało się nawrócenie do Boga ${ }^{97}$. Przez swoją mękę i śmierć Chrystus pokonał zło, aby odtąd ludzie mogli czuć się bezpieczni i odnaleźli pokój ${ }^{98}$.

Na koniec możemy stwierdzić, że Hieronim zaprezentował się w Komentarzu nie tylko jako wyśmienity egzegeta, posługujący się typologią, ale także jako teolog, który starał się dać czytelnikowi pouczenie teologiczne. Słowo Boże było dla niego najwyższym autorytetem i dlatego w nim szukał przede wszystkim argumentacji dla swoich przekonań. Uznając jedność Starego i Nowego Testamentu, chciał wykorzystać wszystko to, co niosły ze sobą starotestamentalne obrazy i ukazać je jako rzeczywistości, które znalazły nie tylko swoje wypełnienie, ale niejednokrotnie ostateczne i pełne wyjaśnienie w świetle Nowego Przymierza. To przekonanie pozwoliło Hieronimowi uznać w Jonaszu typ Jezusa, a w historii proroka zapowiedź Jego zbawczego dzieła. Prezentując swoje poglądy, dotyczące osoby Zbawiciela, a także odkupieńczej misji, Hieronim włączył się w trwającą dyskusję teologiczną nad głównymi problemami chrystologicznymi i soteriologicznymi swojego czasu. I chociaż Komentarz nie stanowi prezentacji całości doktryny w tym zakresie, to niewątpliwie dotyka najważniejszych prawd, ciągle aktualnych nie tylko dla chrześcijan współczesnych św. Hieronimowi.

Ponadto lektura jego Komentarza pozwala dostrzec, jak bardzo Hieronim umiłował Pismo Święte i starał się je jak najlepiej objaśnić. Pozostaje dla nas niedoścignionym wzorem człowieka Biblii, którego całe życie upłynęło w służbie rozumienia i interpretacji Słowa Bożego ${ }^{99}$.

Kończymy nasze rozważania słowami papieża Benedykta XVI, który w jednej ze swoich katechez środowych mówił: „Czego możemy się nauczyć od Hieronima? Wydaje mi się, że przede wszystkim umiłowania słowa Bożego w Piśmie Świętym. Św. Hieronim mówi «Nieznajomość Pisma Świętego jest nieznajomością Chrystusa". Dlatego ważne jest, by każdy chrześcijanin żył w kontakcie i osobistym dialogu ze słowem Bożym, przekazanym nam w Piśmie Świętym"100.

97 JonKom, I, 15, s. 105.

98 JonKom, II, 4b, s. 112.

99 A. Eckmann, dz. cyt., s. 422, 424.

100 Katecheza z dnia 7 listopada 2007, s. 51. 


\section{Giona come figura di Cristo alla luce del Commento al Libro di Giona di San Girolamo}

\section{Riassunto}

San Girolamo è famoso soprattutto per la sua prima traduzione completa in lingua latina della Bibbia, la cosiddetta Vulgata, il testo «ufficiale» della Chiesa latina, che è stato riconosciuto come tale dal Concilio di Trento e che, dopo la recente revisione, rimane il testo «ufficiale» della Chiesa di lingua latina. Come dice di lui il Papa Benedetto XVI, Girolamo «è un Padre della Chiesa che ha posto al centro della sua vita la Bibbia: l'ha tradotta nella lingua latina, l'ha commentata nelle sue opere e soprattutto si è impegnato a viverla concretamente nella sua lunga esistenza terrena, nonostante il ben noto carattere difficile e focoso ricevuto dalla natura». Secondo Girolamo, accostare i testi biblici, soprattutto il Nuovo Testamento, è essenziale per il credente, perché «ignorare la Scrittura è ignorare Cristo» (Commento ad Isaia, prol.). E' sua questa celebre frase che è stata citata anche dal Concilio Vaticano II nella Costituzione Dei Verbum (n. 25).

La profonda preparazione letteraria, la vasta erudizione e la perfetta conoscenza dellebraico biblico consentirono a Girolamo, non solo la revisione e la traduzione di molti testi biblici, ma anche la redazione di parecchi commenti a tali libri. Tra il luglio e il dicembre del 396 fu composto il Commento a Giona (In Ionam). Nella prefazione Girolamo esprime la sua intenzione d'interpretare la persona e la vita del profeta Giona come figura di Gesù e della Sua opera salvifica; tale criterio viene confermato nel seguito del Commento. Anche se l'autore è teso a denunciare e a ridurre l'uso acritico ed esasperato dell'interpretazione spirituale, la sua opera è interamente percorsa da una tendenza ostinatamente tipologica. Citiamo a proposito, un passo molto significativo: «[...] il Libro del profeta Giona non potrà essere riferito per intero al Signore, senza incorrere nel rischio di un'esegesi scorretta. Né per il fatto che nel Vangelo si dice: "Questa generazione malvagia e crudele chiede un segno, ma non le sarà dato altro segno se non quello di Giona: come Giona, infatti, stette tre giorni e tre notti nel ventre del pesce, così il Figlio dell'uomo starà tre giorni e tre notti nel cuore della terra", le altre vicende narrate nel Libro di questo profeta si riferiscono allo stesso modo al Cristo. D'altra parte, dovunque questo rapporto potrà essere istituito senza pericolo di sbagliare, noi cercheremo di farlo» (In Ionam, I, 3b - la traduzione italiana del testo, Girolamo, Commento al Libro di Giona, traduzione, introduzione e note a cura di Nicoletta Pavia, Roma 1992, p. 46).

Partendo da questo principio, Girolamo cita prima il testo biblico nella doppia traduzione latina dalla lingua ebraica dell'originale e dalla traduzione greca dei Settanta, segnalando eventuali divergenze testuali. Poi segue il suo commento, la cui struttura é fondamentalmente binaria: senso letterale e senso spirituale. 
Nella ricerca del primo senso Girolamo é solito appellarsi al contesto filologico, storico e geografico e la sua interpretazione letterale basata sul testo originale, acquista sempre più spazio e importanza. Ma questa tendenza non significa che l'autore si converta alla nuda lettera, piuttosto pensa che l'interpretazione sprirituale debba essere adattata al senso storico.

Nonostante questa tendenza all'interpretazione letterale, Girolamo riconosce il fondamentale significato cristologico della vicenda di Giona ed interpreta tipologicamente molti particolari della vita del profeta come figure o tipi riferiti alla persona e alla storia del Cristo: il nome di Giona, interpretato come "la Colomba» (In Ionam I, 1-2), «il Dolente» (In Ionam I, 1-2) oppure «Figlio della verità» (In Ionam, prol.), prefigura la persona, la divinità e la missione del Cristo ; la fuga del profeta a Tharšiš, lontano dalla presenza del Signore viene interpretata in riferimento all'incarnazione di Gesù (In Ionam I, 3a) e alla sua partecipazione alle tristezze ed alle angosce di questo mondo (In Ionam I, 5b); l'episodio di Giona precipitato in mare viene considerato come tipo della passione e della morte di Gesù (In Ionam I, 3b), invece l'atto del placare il mare raffigura i frutti della sua morte: «la sicurezza della fede, la pace del mondo, la tranqullità dell'universo, la conversione a Dio» (In Ionam I, 15) per l'intera creazione.

L'interpretazione tipologica e cristologica permette a Girolamo di esprimere le sue principali idee teologiche: Gesù aveva la preesistenza eterna presso il Padre; è il Figlio di Dio uguale al Padre secondo la divinità; nel mistero dell'incarnazione Egli non assunse soltanto l'aspetto umano, ma pienamente la natura umana, cioè fu veramnte uomo, pur rimanendo allo stesso tempo Dio e visse tutta l'esistenza umana, compresi gli affetti, i sentimenti, le sofferenze e la morte. La sua morte redentrice sulla croce viene considerata come un sacrificio che porta all'umanità intera il dono della salvezza, grazie all'obbedienza assoluta di Gesù alla volontà del Padre. La sua morte fece salire a Dio il genere umano.

La lettura del Commento a Giona permette di notare la sensibilità filologica di Girolamo che avvertì l'esigenza di concedere maggior spazio all'interpretazione letterale del testo profetico, senza però rinunciare all'interpretazione spirituale, particolarmente quella tipologica in chiave cristologica. Così anche questa breve opera di Girolamo conferma pienamente l'opinione del Papa Benedetto XV che lo ha riconosciuto «dottore eminente nell'interpretazione delle Sacre Scritture». 